INDEPENDENT JOURNAL OF MANAGEMENT \& PRODUCTION (IJM\&P)

http://www.ijmp.jor.br $\quad$ v. 11, n. 9, Special Edition (Baltic States), November 2020 ISSN: 2236-269X

DOI: $10.14807 /$ ijmp.v11i9.1440

\title{
INSTITUTIONALISM IN ACCOUNTING: A REQUIREMENT OF THE TIMES OR A MECHANISM OF SOCIAL PRESSURE?
}

\author{
Nataliia Semenyshena \\ Western Ukrainian National University \\ State Agrarian and Engineering University in Podilya, Ukraine \\ E-mail:natviksem@gmail.com
}

Svitlana Sysiuk

Western Ukrainian National University, Ukraine

E-mail: svitva0406@ukr.net

Kateryna Shevchuk

National University of Life and Environmental Sciences of Ukraine, Ukraine

E-mail: katerynashevchuk@nubip.edu.ua

Western Ukrainian National University, Ukraine
E-mail: innapetruk10@gmail.com

Iryna Benko

Western Ukrainian National University, Ukraine

E-mail: idbenko@gmail.com

Submission: 8/30/2020

Accept: 9/8/2020

\section{ABSTRACT}

The purpose of the study is to establish and identify the reasons for the formation of the institutional foundations of accounting, substantiate their advantages and disadvantages for Ukraine, as well as build an effective organizational and institutional architectonics of its development. The institutional influence on the accounting system in Ukraine and its reasons are established on the basis of an empirical generalization of the positions of various authors, as well as a critical analysis of the existing norms and practices. The method of regression analysis was used to select the basic branch of the national economy, on the example of which the study was conducted. It is substantiated that objectively this influence is associated with social and international requirements, however, for agricultural enterprises, the prerequisite for the introduction of institutional frameworks is the desire of these entities for international cooperation. 
DOI: 10.14807/ijmp.v11i9.1440

The above arguments are based on the analysis of statistical data, the results of a questionnaire survey of 105 heads of Ukrainian agricultural companies. An empirical generalization was carried out on the basis of a critical assessment of the normative and legal framework for the development of accounting and accounting for the results of the survey, which made it possible to assess the genesis of the introduction of institutional accounting frameworks in the agricultural sector of Ukraine and substantiate the objective need for such a process. It has been proved that the discussion on the objectivity or compulsory development of the institutional foundations of accounting has real ground. For this purpose, for comparison, the results of a questionnaire survey of managers and accounting specialists in the public sector and indicators of the dynamics of the availability of funds in the single treasury account as of January 1 in recent years are presented, which made it possible to conclude that there are no objective reasons for the institutionalization of accounting and its compulsory nature in this sector.

It follows from the study that the institutionalization of accounting is both an objective requirement of the time and a mechanism of public pressure at the same time. Its assignment to one category or another is determined by the existing needs, the branch of the national economy and the results that can be obtained.

Keywords: Institutional Accounting; IFRS; Coercive isomorphism; Agrarian Accounting; Public Accounting

\section{INTRODUCTION}

Modern global challenges and the specifics of national economic systems actively influence accounting as an information source for making managerial decisions in business matters. With this in mind, the accounting system is developing on a new basis. One of these foundations is institutionalism. Despite its long history, he and his accounting principles began to be implemented relatively recently.

In Ukraine, the problem of "institutional accounting theory" has become the subject of scientific discussion in recent years. This term only in general terms defines the essence of the positions, but in our study it is used because it contains the main identification feature of the basis for the development of modern accounting theory in Ukraine - institutionalism.

The study of the topic of institutionalism in accounting is important for several reasons: firstly, to establish the true reason for its implementation in this area; secondly, in order to find 
DOI: 10.14807/ijmp.v11i9.1440

possible ways to improve accounting and maximize the use of institutional frameworks for these purposes.

The complexity of the problem of development of accounting and its theory is associated with the specifics of its method, which consists of quite specific elements. Therefore, institutionalism as a concept that combines the results of the activities of various institutions and forms the basis of accounting provides a synthesis of new approaches, like no other basic theory can develop these elements and, thus, actively influences the accounting method as a whole.

The historical experience of the development of accounting indicates the presence of many significant elements that indicate the influence of institutionalism on the system and theory of accounting. It seems to us important to establish the reasons for the spread of this theory in the Ukrainian accounting science. Ukraine has specific conditions, and therefore, in particular in this context, the issue of institutionalism in accounting is relevant - this is a time requirement or a mechanism of public pressure, which is implemented at the request of the state or international organizations.

\section{LITERATURE REVIEW}

Aldemir and Uysal (2017) point to the significant influence of institutionalism in accounting on the example of Turkey. They proved the following statement: "It is revealed that the regulatory arrangements directly contribute to the institutionalization of a field, and as a result, how the public organizations directly contribute to the institutionalization process”. In addition, the authors presented the results of their research into the history of the introduction of institutional frameworks into accounting for various sectors of the Turkish economy. The greatest impact of institutionalism is, as evidenced by their research, accounting in the financial sector (financial system). This is due to its importance in the Turkish economy and the development of international relations and trade.

In contrast to this view, which presents the institutional framework of accounting as an objective necessity to enable the Turkish economy to develop better, Carpentera and Feroz (2001) argued that institutional accounting theory is institutional pressure. As an example, the authors cite the types of pressure on the US state governments to adopt GAAP principles. At the same time, the authors believe that if accountants do not participate in professional associations, then they may miss the opportunity to gain new knowledge. 
DOI: 10.14807/ijmp.v11i9.1440

Guerreiro, Rodrigues and Craig (2020) take the position that institutional theory allows a better and deeper understanding of the processes of change associated with the adoption and implementation of international accounting standards. However, the authors believe that the latter can be described as coercion to unification.

In their next study, Guerreiro, Rodrigues and Craig (2020) covered in more detail the impact of institutional theory on the accounting systems of different countries through the introduction of international standards, identified shortcomings and formed options for overcoming them.

Khadaroo (2005), examining the process of setting private financial initiative (PFI) accounting standards in terms of institutional theory, also believes that this is the result of public pressure. It defines two forms of institutional pressure, the "compulsory" pressure of the Treasury and the "regulatory" pressure exerted by accounting organizations. At the same time, the author argues that the views of the accounting profession probably prevailed in the process of setting PFI standards.

In Ukraine, the opinions of scholars on the impact of institutionalism on the theory and practice of accounting are mostly positive.

Zhuk (2012), who actively researched and promoted the feasibility of institutional approaches in accounting science and from this position considered "the subject of accounting as a professional reflection of processes and phenomena of life of organizations (enterprises) and assessment of institutional impacts on such processes and changes in life", considers institutionalism to be a progressive phenomenon that has arisen due to the objective need to improve accounting.

A number of authors believe that the introduction of an institutional approach to the theory of accounting has expanded its functions, complementing the traditional information, control and analytical following: coordinating and distributive (GONCHARENKO, 2013), service and consulting (KOLESNIKOVA, 2013), scientific, social, regulatory and prognostic (SEMANYUK, 2012), communicative (SEMENYSHENA, 2016).

At the same time, Ukrainian authors (GONCHARENKO, 2013; KOLESNIKOVA, 2013; SEMANYUK, 2012; SEMENYSHENA, 2016), as well as foreign (NAGENDRAKUMAR, 2019), believe that the institutionalization of accounting is positive and contributes to the development of the accounting profession. 
DOI: $10.14807 /$ ijmp.v11i9.1440

Moreover, this approach began to develop in relation to management accounting. In particular, research by Ribeiro and Scapens (2016) is devoted to this direction. Exploring such theories as "old institutional economics" and "new institutional sociology", the authors were able to propose ways of developing these theories and, in general, to develop an institutional understanding of changes in management accounting, as well as to identify the advantages and disadvantages of this process (RIBEIRO; SCAPENS, 2006).

Our previous research (SEMENYSHENA; KHORUNZHAK; ZADOROZHNYI, 2020) has established the essence and identification of the components of the institutional theory of accounting and substantiated the role and influence of these components on the national economy on the example of standardization.

The presence of different positions regarding the influence of the institutional framework on the accounting system is probably associated with the results that are obtained after their application in a particular country in a particular accounting system and even the branch of the national economy in which this accounting is kept.

The purpose of the study is to establish and identify the reasons for the formation of the institutional foundations of accounting, substantiate their advantages and disadvantages for Ukraine, as well as build an effective organizational and institutional architectonics of its development.

\section{METHODOLOGY}

\subsection{Method of choosing the basic branch of the national economy of Ukraine for the study}

To establish the true results, it is important to analyse in detail the positive and negative consequences of institutionalization in accounting and this will allow adequately assessing the situation. Moreover, given the poly-criteria of this influence, its assessment should be based on the effective integral indicator. Our observations of pragmatics and study of theory allow us to make a superficial conclusion that institutional theory in accounting and its influence also depends on the branch of the economy.

Based on this, it is advisable, when choosing a branch of the national economy, on the basis of which research will be carried out, to take into account its role and importance in the economy of the state. For Ukraine, according to many researchers, this is the agrarian sector. To prove this assumption, we applied the method of correlation analysis of the influence of various sectors of the national economy on the formation of the country's GDP. To identify the 
DOI: 10.14807/ijmp.v11i9.1440

degree of influence and detailed accounting of the components of each of the industries (we call them influencing factors), we established their dependence on the indicators that determine them, or form GDP. For example, the share of regions of Ukraine in the national GDP ( $Y$ ), as evidenced by official statistics, depends on the development of agriculture, forestry and fisheries $\left(x_{1}\right)$, processing industry $\left(x_{2}\right)$, extractive industry, quarrying $\left(x_{3}\right)$, construction development $\left(x_{4}\right)$, production and distribution electricity, gas and water $\left(x_{5}\right)$, the activities of hotels and restaurants $\left(x_{6}\right)$, trade, car repairs, household goods and personal consumption ( $x_{7}$ ), financial and insurance activities $\left(x_{8}\right)$, transport and communications $\left(x_{9}\right)$, public administration $\left(x_{10}\right)$, operations with real estate, rent, engineering and provision of services to entrepreneurs $\left(x_{11}\right)$, health care and social assistance $\left(x_{12}\right)$, education $\left(x_{13}\right)$, provision of communal and individual services and activities in the field of culture and sports $\left(x_{14}\right)$. Taking this into account, we have built a formalized mathematical model that will indicate the degree of influence of each of the components (indicators) on the region's share in the national GDP:

$$
Y=\beta_{j}+\sum_{i=1}^{14} \alpha_{i} x_{i}
$$

where are $\alpha_{i}$ - the weight coefficients that indicate the degree of influence of each indicator on the effective one, that is, on the indicator of the region's share in the national GDP, and these coefficients are determined on the basis of correlation and regression analysis; $\beta_{j}$ - free term of linear regression of the j-th region.

Based on statistical data (MINISTRY OF DEVELOPMENT OF COMMUNITIES AND TERRITORIES OF UKRAINE, 2020; MINISTRY OF REGIONAL DEVELOPMENT, CONSTRUCTION AND HOUSING AND UTILITIES OF UKRAINE, 2016-2019), having formed a regression model in the Excel environment, we obtained the weight coefficients and free terms of the linear regression of the j-th region. As a result of this, weights and free terms of the linear regression of the j-th region are obtained, which are presented in Table 1.

Conducted research based on the regression model indicate that some indicators do not affect the region's share in the national GDP, for example: the development of the processing industry in the Rivne region, the mining industry, quarrying in the Kyiv, Mykolayiv, Cherkasy regions, etc., and some have an exceptional impact on most regions of Ukraine. For example, agriculture for 11 regions of Ukraine (Kharkiv, Poltava, Rivne, Ivano-Frankivsk, Lviv, Dnipro, 


\section{INDEPENDENT JOURNAL OF MANAGEMENT \& PRODUCTION (IJM\&P)}

http://www.ijmp.jor.br

v. 11, n. 9, Special Edition (Baltic States), November 2020

ISSN: 2236-269X

DOI: 10.14807/ijmp.v11i9.1440

Chernivtsi, Zakarpattia, Lugansk, Vinnytsia, Ternopil) out of 24 (that is, in $45.8 \%$ of regions out of 100) has an exceptional influence on the formation of GDP.

That is, the agriculture of these regions makes a significant contribution to the volume of national GDP, and therefore this industry can and should be taken as a basis for research, in particular, regarding the direction we have chosen.

Table 1: Analytical expressions of the share of GDP in the total volume and their dependence on the branches of the national economy in the context of regions of Ukraine

\begin{tabular}{|c|c|c|c|c|c|c|c|c|c|c|c|c|c|c|c|}
\hline \multirow{2}{*}{$\begin{array}{l}\text { Region of } \\
\text { Ukraine }\end{array}$} & \multicolumn{14}{|c|}{ WEIGHTS $\alpha_{i}$} & \multirow[b]{2}{*}{$\beta_{j}$} \\
\hline & $\alpha_{1}$ & $\alpha_{2}$ & $\alpha_{3}$ & $\alpha_{4}$ & $\alpha_{5}$ & $\alpha_{6}$ & $\alpha_{7}$ & $\alpha_{8}$ & $\alpha_{9}$ & $\alpha_{10}$ & $\alpha_{11}$ & $\alpha_{12}$ & $\alpha_{13}$ & $\alpha_{14}$ & \\
\hline & 234 & 0.383 & -1.030 & 125 & 0.053 & -0.018 & 0 & -0.592 & 0.358 & 096 & .074 & .362 & -0.386 & -0.142 & .507 \\
\hline Voly & & 2.758 & 5.243 & & -7.609 & -0.924 & 0.495 & 1.149 & -0.920 & & 2.244 & & -3.407 & 1.137 & 12.823 \\
\hline Dnipr & 218 & -0.242 & 0.236 & 398 & -0.424 & 0.148 & -0.265 & 0.089 & -0.999 & 1.113 & .074 & & -0.805 & 0.263 & 17.729 \\
\hline Dor & -0.104 & 0.229 & -0.027 & 058 & -0.160 & 0.604 & 25 & -0.047 & 0.202 & -0.638 & 0.141 & 0 & 0.607 & 0.201 & 2.837 \\
\hline Zhyt & -0.135 & -0.201 & 0.082 & -0.039 & 0.255 & 0.088 & -0.139 & 0.245 & 1.469 & 0.443 & -1.503 & 0 & -0.565 & 0.905 & 0.111 \\
\hline Zak & 0151 & -0.048 & -0.0105 & -0.0236 & 0.118 & -0.111 & 0.247 & 0.402 & 0.107 & 0 & 0.302 & 0.560 & -0.769 & -0.049 & 0.985 \\
\hline Zap & -0.4 & 0.017 & -0.212 & 3 & 0.193 & -0.174 & 0.364 & 0.043 & -0.143 & S & 0.318 & 0.180 & 0.094 & -0.301 & 2.379 \\
\hline $\begin{array}{r}\text { Iva } \\
\text { Franl }\end{array}$ & 0.281 & 0.355 & 0.3 & & -0.085 & -0.196 & 0. & 0.240 & 0.745 & 20 & -0.176 & 0 & -0.060 & 0.614 & -2.889 \\
\hline & & 0.077 & 0 & & -0.029 & 009 & & 0.017 & 0.146 & -0.006 & -0.160 & 1.247 & -0.176 & 0.024 & -1.767 \\
\hline Kirov & 0.234 & -0.103 & -0.077 & 59 & 0.145 & 0.248 & 0.329 & 0.024 & 0.197 & -0.019 & -0.402 & 0.190 & 0 & -0.506 & 0.275 \\
\hline Lul & 0.869 & 0.054 & 0.171 & -0.932 & 0.123 & 0.243 & -0.036 & -0.373 & -0.079 & -0.035 & 0.614 & 0.1883 & 0 & -0.031 & -0.617 \\
\hline & 0.262 & 0.265 & 0.066 & & -0.040 & -0.009 & 0.2 & 0.146 & 0 & & 0.237 & 3 & 0.049 & -0.037 & 0.862 \\
\hline Myk & $=0.0 / 0$ & 0.055 & 0 & & -0.029 & 0.567 & 0.456 & 0.127 & 0.181 & 0.512 & 0.238 & -1.546 & 0.238 & -0.254 & 1.324 \\
\hline $\mathrm{Oc}$ & -3.343 & 3.484 & 20.599 & 193 & -1.241 & 2.319 & 0 & -0.714 & -1.973 & -0.577 & -1.813 & -1.802 & 0.716 & 4.097 & 10.308 \\
\hline Pol & 0.087 & 0.708 & 0.044 & -0.339 & 0.594 & 0.314 & 0.083 & 0.088 & -0.238 & -0.270 & -0.206 & 0 & 0.470 & 0.538 & -3.098 \\
\hline Rivn & 0.095 & 0 & -0.059 & 0.035 & 0.006 & 0.002 & 0.283 & 0.012 & -0.203 & -0.102 & -0.322 & 0.105 & 0.212 & 0.254 & 0.510 \\
\hline & -0.148 & 0.377 & 0.057 & & -0.202 & 0.076 & 0.043 & -0.352 & 0.374 & 0.272 & -0.218 & 1.478 & 0 & -1.177 & -0.434 \\
\hline Tern & 0.091 & 0.344 & -0.918 & 0.099 & -0.062 & 0.185 & -0.720 & -0.030 & -0.135 & 0.280 & -0.132 & 0 & 0.467 & -0.138 & 0.189 \\
\hline Kharkivska & 0.309 & 0.076 & 0.054 & \begin{tabular}{|l|}
0.041 \\
\end{tabular} & -0.076 & -0.027 & 0.251 & 0.129 & -0.226 & 0 & 0.004 & 0.137 & 0.518 & 0.227 & -3.291 \\
\hline ka & -0.482 & $-(-10$ & 0.688 & 717 & 0.823 & -0.395 & 0 & 0.530 & -1.293 & \begin{tabular}{|l|l|} 
& 0.277
\end{tabular} & -1.550 & 2.004 & 1.323 & 0.032 & -2.661 \\
\hline Khm & -0.078 & 0.710 & -0.562 & 0.480 & 0.063 & -1.259 & 0.918 & 0.320 & -0.235 & -0.219 & 0.559 & 1.283 & 0.965 & 0 & -5.355 \\
\hline & -0.201 & -0.163 & 0 & -0.339 & -0.447 & 0.700 & 0.422 & -0.093 & 0.756 & 0.781 & 0.589 & -0.475 & -0.185 & 0.407 & 0.485 \\
\hline Chern & 0.104 & -1.179 & -0.271 & 0.123 & 0.014 & 0.537 & 0 & 0.462 & -0.142 & -0.046 & 0.162 & -0.738 & -0.107 & -0.020 & 1.593 \\
\hline Chernihivska & -0.068 & 0.329 & -0.009 & 0.191 & 0.098 & 0.099 & 0 & -0.261 & 0.076 & 0.001 & 0.409 & 0.108 & 0.915 & -0.109 & -1.190 \\
\hline
\end{tabular}

Source: calculated by the authors

\subsection{Technical research methods}

The questionnaire method was used in the process of conducting the research to ensure that the position of practitioners was taken into account. This method is applied in 3 regions of Ukraine - Vinnytsia, Rivne, and Ternopil regions, in which agriculture is an important factor in the formation of GDP.

The sector is selected from the list established on the basis of the results of regression analysis of the impact of various sectors of the economy on Ukraine's GDP in the context of its regions. 105 respondents took part in the questionnaire survey. The results are summarized in Table 2. 
INDEPENDENT JOURNAL OF MANAGEMENT \& PRODUCTION (IJM\&P)

http://www.ijmp.jor.br

v. 11, n. 9, Special Edition (Baltic States), November 2020

ISSN: 2236-269X

DOI: 10.14807/ijmp.v11i9.1440

Table 2: Results of the survey of heads of agricultural holdings and small farms on the feasibility of applying the institutional accounting framework *

\begin{tabular}{|c|c|c|c|c|c|c|c|}
\hline \multirow[t]{2}{*}{ Question } & \multicolumn{7}{|c|}{ Categories of managers (levels of management) of the enterprise } \\
\hline & $\begin{array}{l}\text { Manager } \\
\text { (director) }\end{array}$ & $\mathrm{CFO}$ & $\begin{array}{c}\text { Chief } \\
\text { Accountant }\end{array}$ & $\begin{array}{c}\text { Head of } \\
\text { marketing } \\
\text { department }\end{array}$ & $\begin{array}{c}\text { Head } \\
\text { economist }\end{array}$ & $\begin{array}{c}\text { Chief } \\
\text { mechanical } \\
\text { engineer }\end{array}$ & $\begin{array}{c}\text { Chief } \\
\text { technologist }\end{array}$ \\
\hline $\begin{array}{l}\text { Is there a need } \\
\text { to apply IFRS }\end{array}$ & $15 / 4$ & $15 / 5$ & $15 / 5$ & $15 / 3$ & $15 / 5$ & $4 /-$ & $5 /-$ \\
\hline $\begin{array}{l}\text { Is there a need } \\
\text { for a } \\
\text { professional } \\
\text { organization }\end{array}$ & $15 / 15$ & $15 / 15$ & $15 / 15$ & $15 / 3$ & $15 / 15$ & $-/ 1$ & $4 / 5$ \\
\hline $\begin{array}{l}\text { Is the influence } \\
\text { of state } \\
\text { institutions } \\
\text { important? }\end{array}$ & $10 / 2$ & $11 / 3$ & $9 / 15$ & $12 /-$ & $12 / 15$ & $-/ 3$ & $3 / 7$ \\
\hline $\begin{array}{l}\text { Is there a need } \\
\text { to take into } \\
\text { account } \\
\text { national } \\
\text { specifics? }\end{array}$ & $12 / 15$ & $15 / 15$ & $15 / 15$ & $15 / 15$ & $15 / 15$ & $15 / 15$ & $15 / 15$ \\
\hline $\begin{array}{c}\text { Are } \\
\text { international } \\
\text { approaches } \\
\text { (provisions of } \\
\text { IFRS and IAS) } \\
\text { consistent with } \\
\text { national } \\
\text { specifics? } \\
\end{array}$ & $3 / 4$ & $3 / 8$ & $2 / 7$ & $3 / 5$ & $3 / 8$ & $-/-$ & $-/-$ \\
\hline $\begin{array}{l}\text { Is there a need } \\
\text { for a significant } \\
\text { change in the } \\
\text { educational } \\
\text { institutional } \\
\text { component for } \\
\text { training } \\
\text { accounting } \\
\text { specialists } * * \\
\end{array}$ & $9 / 2$ & $8 / 4$ & $10 / 3$ & $9 / 7$ & $9 / 7$ & $-/-$ & $3 / 8$ \\
\hline
\end{tabular}

Note:

* - the number of respondents from each group - 15 people, in this Table the first figures refer to the respondents of the management of agricultural holdings, and through the slash - small and medium-sized farms; this Table summarizes the "yes" answers; author's research;

** - if the answer is "yes" - indicate in the annex to the questionnaire which competencies of the accounting employees should be strengthened. As part of the competencies, the respondents identified: analytical skills, knowledge of a foreign (usually English) language, communication skills

A similar survey was conducted with employees of the public (state) sector to compare the positions of practitioners, which, from the point of view of society, plays an exceptional role in ensuring that the social, cultural, educational, medical and other needs of the population are met.

The results of the survey are summarized in Table 3. 
INDEPENDENT JOURNAL OF MANAGEMENT \& PRODUCTION (IJM\&P)

http://www.ijmp.jor.br

v. 11, n. 9, Special Edition (Baltic States), November 2020

ISSN: 2236-269X

DOI: 10.14807/ijmp.v11i9.1440

Table 3: Results of the questionnaire survey of management workers of public (state) sector entities regarding the appropriateness of the application

of the institutional accounting framework *

\begin{tabular}{|c|c|c|c|c|c|c|c|}
\hline \multirow[t]{2}{*}{ Question } & \multicolumn{7}{|c|}{ Categories of managers (levels of management) } \\
\hline & $\begin{array}{c}\text { Chief } \\
\text { budgetary } \\
\text { managers, } \\
\text { government } \\
\text { officials }\end{array}$ & $\begin{array}{l}\text { Head of a } \\
\text { budgetary } \\
\text { institution }\end{array}$ & $\begin{array}{c}\text { Deputy } \\
\text { head of a } \\
\text { budgetary } \\
\text { institution }\end{array}$ & $\begin{array}{c}\text { Chief } \\
\text { accountant } \\
\text { of a } \\
\text { budgetary } \\
\text { institution }\end{array}$ & $\begin{array}{l}\text { Head of } \\
\text { the } \\
\text { marketing } \\
\text { department } \\
\text { of a } \\
\text { budgetary } \\
\text { institution }\end{array}$ & $\begin{array}{l}\text { Chief } \\
\text { economist } \\
\text { of a } \\
\text { budgetary } \\
\text { institution }\end{array}$ & $\begin{array}{c}\text { Deputy } \\
\text { chief } \\
\text { accountant } \\
\text { of a } \\
\text { budgetary } \\
\text { institution }\end{array}$ \\
\hline $\begin{array}{l}\text { Is there a need } \\
\text { to apply IFRS }\end{array}$ & $15 / 4$ & $15 / 5$ & $15 / 5$ & $15 / 3$ & $15 / 5$ & $4 /-$ & $5 /-$ \\
\hline $\begin{array}{c}\text { Is there a need } \\
\text { for a } \\
\text { professional } \\
\text { organization } \\
\end{array}$ & $15 / 15$ & $15 / 15$ & $15 / 15$ & $15 / 3$ & $15 / 15$ & $-/ 1$ & $4 / 5$ \\
\hline $\begin{array}{l}\text { Is the influence } \\
\text { of state } \\
\text { institutions } \\
\text { important? }\end{array}$ & $10 / 2$ & $11 / 3$ & $9 / 15$ & $12 /-$ & $12 / 15$ & $-/ 3$ & $3 / 7$ \\
\hline $\begin{array}{l}\text { Is there a need } \\
\text { to take into } \\
\text { account } \\
\text { national } \\
\text { specifics? }\end{array}$ & $12 / 15$ & $15 / 15$ & $15 / 15$ & $15 / 15$ & $15 / 15$ & $15 / 15$ & $15 / 15$ \\
\hline $\begin{array}{c}\text { Are } \\
\text { international } \\
\text { approaches } \\
\text { (provisions of } \\
\text { IFRS and IAS) } \\
\text { consistent with } \\
\text { national } \\
\text { specifics? } \\
\end{array}$ & $3 / 4$ & $3 / 8$ & $2 / 7$ & $3 / 5$ & $3 / 8$ & $-/-$ & $-/-$ \\
\hline $\begin{array}{l}\text { Is there a need } \\
\text { for a } \\
\text { significant } \\
\text { change in the } \\
\text { educational } \\
\text { institutional } \\
\text { component for } \\
\text { training } \\
\text { accounting } \\
\text { specialists } * *\end{array}$ & $9 / 2$ & $8 / 4$ & $10 / 3$ & $9 / 7$ & $9 / 7$ & $-/-$ & $3 / 8$ \\
\hline
\end{tabular}

Note: * - the number of respondents from each group - 15 people, in this Table the first figures refer to the respondents of the management of agricultural holdings, and through the slash - small and medium-sized farms; this Table summarizes the "yes" answers; author's research; ** - if the answer is "yes" - indicate in the annex to the questionnaire which competencies of the accounting employees should be strengthened. As part of the competencies, the respondents identified: analytical skills, knowledge of a foreign (usually English) language, communication skills

These results were further used to substantiate the author's conclusions on solving the problem of establishing the true reason for institutionalization in accounting. 
DOI: 10.14807/ijmp.v11i9.1440

\section{RESULTS AND DISCUSSIONS}

\subsection{Institutionalization of accounting in Ukraine, its reasons and main characteristics}

Perhaps it was precisely these arguments, which were obtained as a result of the application of the regression assessment and the questionnaire survey, that were guided by government agencies when they decided to formulate the Concept for the development of accounting in the agricultural sector of the Ukrainian economy (2009), which substantiated the need to improve this system, focusing on national needs, expanding the capabilities of the management process in accordance with the professionalism of accountants and the level of their ability to self-organize in the uncertain conditions of the functioning of enterprises.

It was this document that helped highlight the social factor as an important lever of influence on accounting practice, gave impetus to the development of accounting theory, focusing on economic institutions. An assessment of recent studies shows that there is an increasing interest in accounting in the social and economic plane, especially this trend is observed due to the standardization of accounting in the context of globalization.

In modern conditions of development of society, the theory of accounting lags behind practice, since the rapid social and economic development requires an instant response to changes in the environment. Therefore, it is logical to assume that the development of accounting is directly proportional to the development of economic science, and therefore accounting science needs to be improved, focusing on the economic institutional theory. This direction of the study was determined by the fact that the institutional theory is classic about the modern development of the economic platform. The main reason for its application is the fact that it determines the factors of influence and directions of development of the system of institutions in order to overcome problems, and explains the reasons for the formation of an effective or ineffective economic system.

In Ukraine, the institutional accounting framework has been implemented in almost all sectors of the national economy. A striking example of this is the unification of accounting through the adoption of accounting standards based on international ones for all industrial sectors (P(S)A and the unified Chart of accounts for accounting assets, capital, liabilities and business transactions of enterprises and organizations), banks (in the context of IFRS and Chart of Accounts for Ukrainian banks) and the public sector (NS ASS and Chart of accounts for public sector accounting). 
DOI: 10.14807/ijmp.v11i9.1440

Such changes were made taking into account the fact that the application of the institutional theory in practice will allow for an effective change of institutions in order to achieve the set strategic goals.

To achieve a comprehensive study of institutional theory, it is necessary to conduct it in stages and in accordance with a model that will allow studying the current state of the theory of accounting institutionalism and, at the same time, directing directions for its improvement (Figure 1).

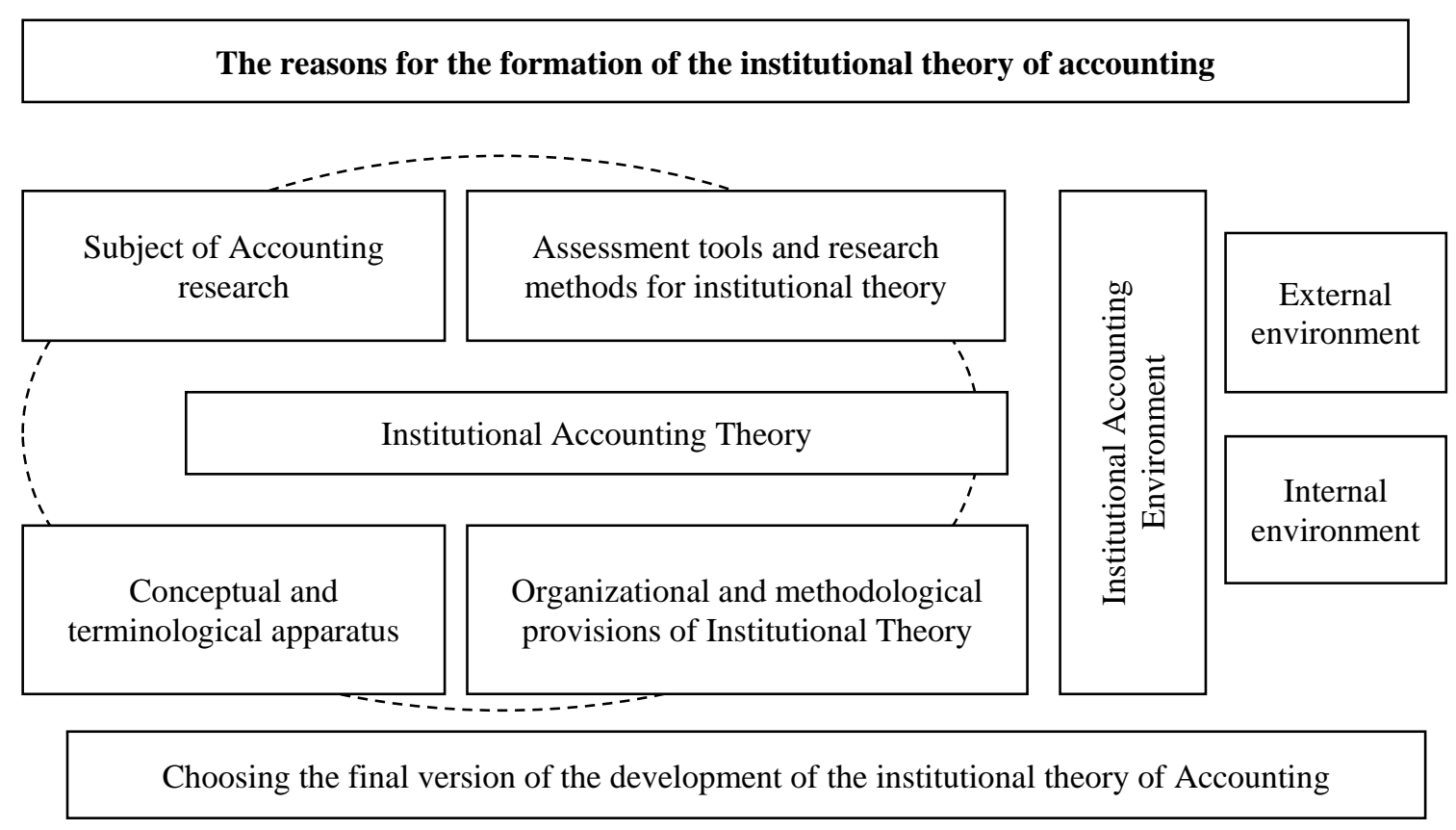

Figure 1: The main elements of the study of the institutional theory of accounting Source: summarized by the authors

Not all of these components will be presented in this study (due to their global nature). However, some elements were used to substantiate the author's conclusions and this is explained as follows. The authors agree that the main reasons for the formation of the institutional theory of accounting are:

- the existence of interdisciplinary links between accounting and economic theory;

- adaptation of economic methods and tools to the practice of accounting in order to solve problematic situations in the accounting area. The effectiveness of the application of economic theory in accounting practice is unproven, but recently many scientific works have been devoted to this topic;

- the emergence of the need to display new accounting objects. In this context, the basic concepts are transaction costs (performance of work, costs of finding information, concluding contracts, securing ownership, providing services, etc.), which are not 
DOI: 10.14807/ijmp.v11i9.1440

related to the production process itself and require separate approaches in accordance with accounting practice focusing on the theory of institutionalism (VYSOCHAN; YAKHVAK, 2017).

At the same time, the institutional theory does not set itself specific requirements and does not contradict the classical management technology, but focuses on the directions of development in the plane of accounting research. And the main elements of her research are: elements of the accounting method as a social and economic institution, factors of influence of the institutional environment, relationships between participants in the institutional environment, the effectiveness of accounting in the institutional environment, etc.

Without focusing on the detailed coverage of the issue of institutionalization of accounting in Ukraine, we note that the implementation of such an idea, in addition to real, objective needs, requires a number of prerequisites. These prerequisites cover various areas of activity, as well as the corresponding institutions of implementation.

In particular, Voskresenskaja and Lvova (2011), distinguishes these conditions and rightly believes that the main elements of the institutional provision of accounting in general are formal and informal institutions, the composition of which is shown in Figure 2.
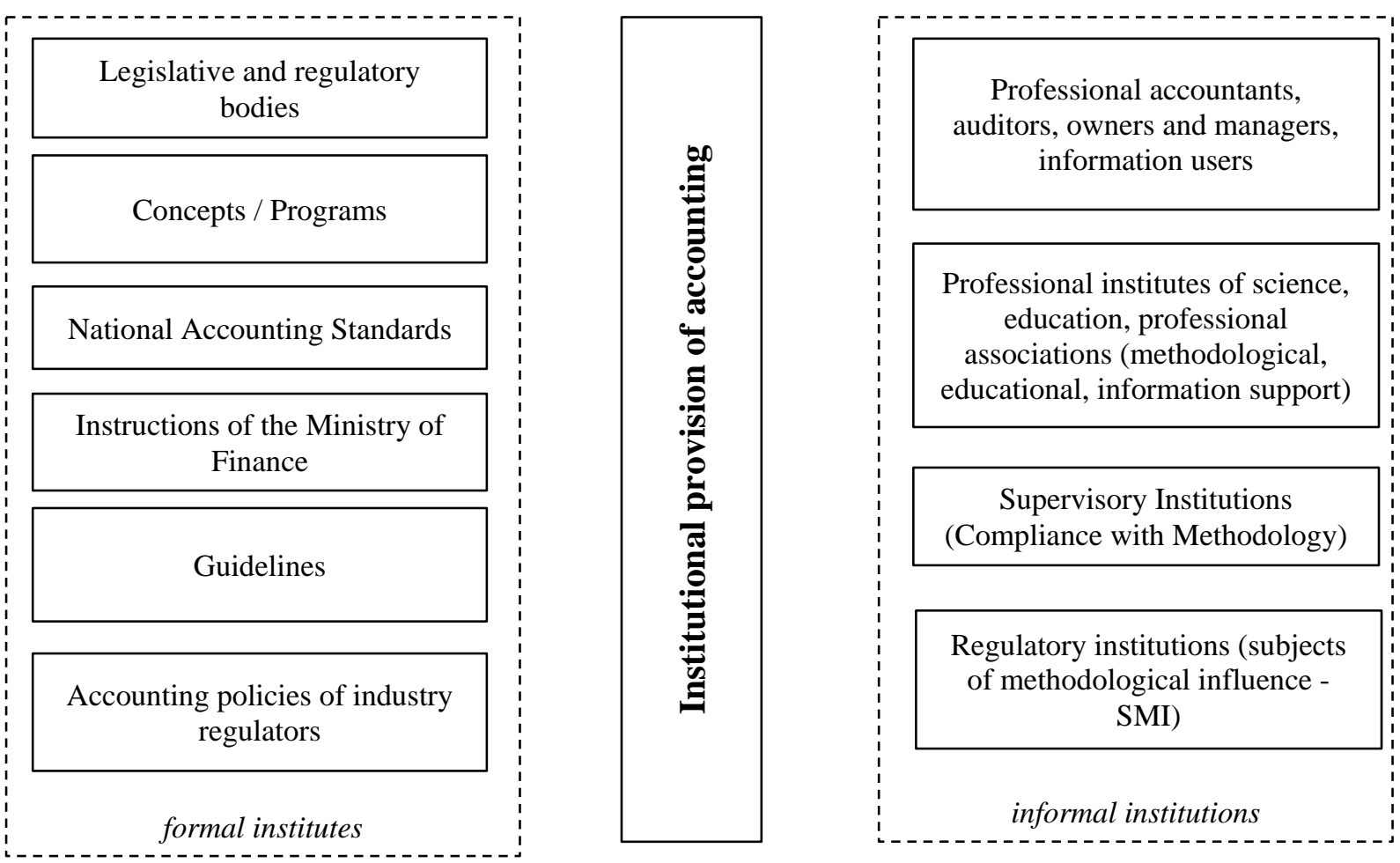

Figure 2: Elements of institutional support for the development of accounting in Ukraine Source: compiled by the authors for VOSKRESENSKAJA and LVOVA (2011). 
DOI: 10.14807/ijmp.v11i9.1440

The institutions presented in Figure 2 create relationships within the institutional environment in accordance with the norms of the activity of formal and informal institutions. They reflect the institutional approach of accounting based on the separation of accounting as the main element of the institutional system.

In this context, Pankov (2011) identifies external and internal factors of influence on the institutional environment, which allow considering the basic characteristics of accounting institutions, analysing the real mechanism of their functioning. The scientist identifies the following external factors: social and cultural attitudes dominating in society; customs and business practices; general legal system; a special regulatory framework governing the rules for keeping records and preparing financial statements; conditions for economic development; technical progress and development of information technologies; general processes of globalization and integration; the system of education and training of specialists, information processes in the professional environment (PANKOV, 2011).

Without going into excessive detailing of the above factors, we note that the first of them in Ukraine contains a significant difference from international practice. In particular, the development and approval of national accounting regulations is not carried out by professional organization (Figure 3), but by the Ministry of Finance of Ukraine, which is a state institution.

\section{(IFRS Foundation Trustees)}

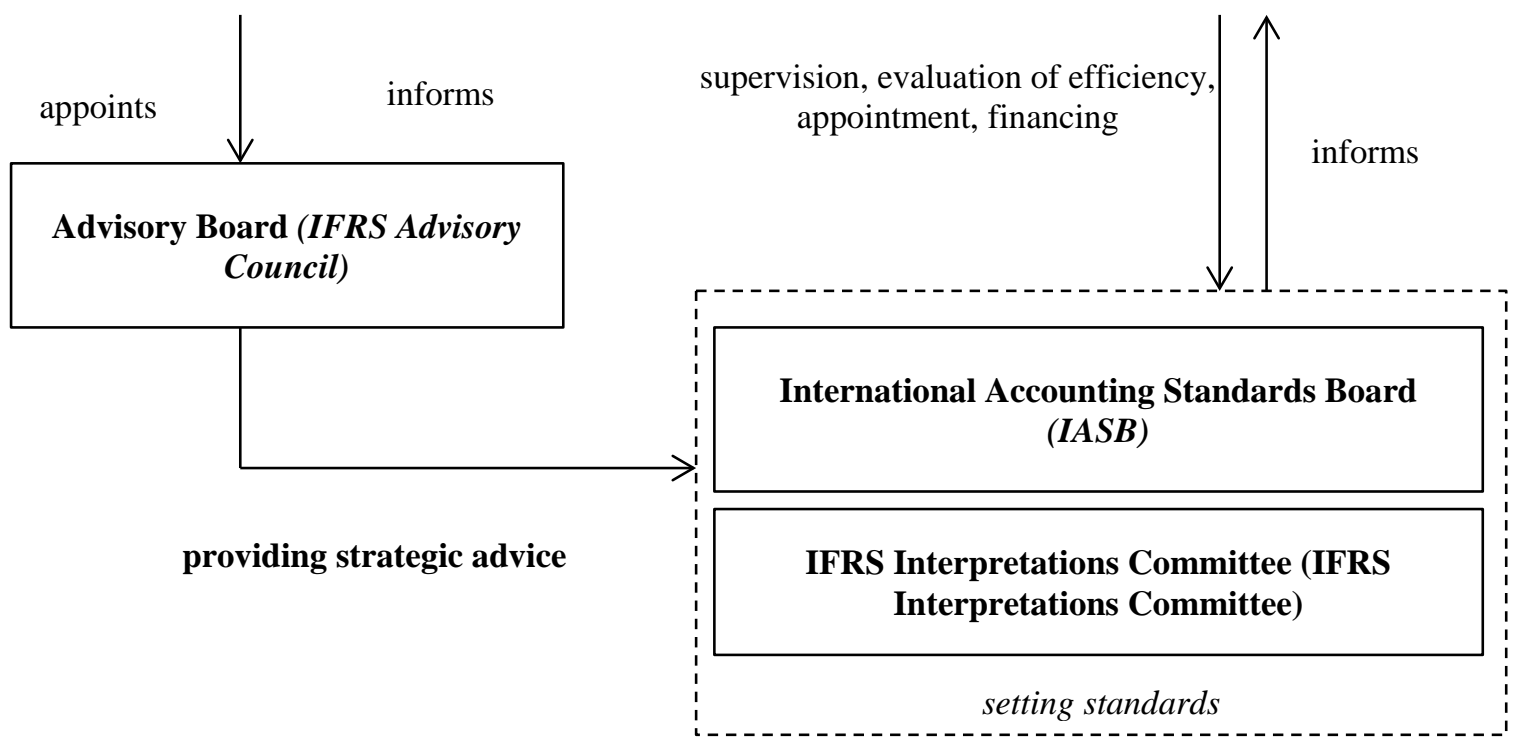

Figure 3: The structure of bodies for the development of international financial reporting standards Source: MELNICHUK, 2011 
That is, in Ukraine, the Ministry of Finance is responsible for the accounting methodology, but there is no controlling body at all. This problem remains open and needs to be addressed. In this perspective, it is proposed to create a new supervisory body for the highquality implementation of IFRS in the country, or to provide these powers to the National Commission on Securities and Stock Market (MELNICHUK, 2011).

In this case, an independent institution is an auditor who, focusing on the interests of society, confirms the reliability of the financial statements given in the official documents of business entities.

Characterizing such an institutional component of accounting as the application of the provisions of international accounting standards, or taking their position as a basis for national accounting standards, it should be pointed out that there are a number of problematic aspects in Ukraine. Certain provisions do not correspond to either the Ukrainian national mentality or the existing conditions for their implementation.

For example, the use of an accrual basis requires effective leverage and a mechanism to settle accounts receivable and appropriate leverage. Unfortunately, such a mechanism in the state is imperfect, and as a way out of the situation, business entities actively practice prepayments for their products (goods or services). This significantly slows down the sales process and negatively affects the performance of enterprises, but, in a certain way, saves business entities from the risks of default on obligations.

There is a certain problem in Ukraine and according to other recommendations of international standards. Therefore, such issues should be given special attention. In general, the implementation of measures to effectively organize the use of IFRS and eliminate their shortcomings will allow the successful functioning of formal and informal institutions in the modern social and economic environment.

These are the main starting points associated with the institutionalization of accounting in Ukraine as a whole, but in the sectoral plan, they have additional features. In particular, it is very important to clearly identify the influencing factors in order to determine whether there is an objective need for the institutionalization of accounting, or, perhaps, it is imposed from the outside by various state or international organizations. 
DOI: 10.14807/ijmp.v11i9.1440

\subsection{Institutionalization of accounting in the agricultural sector of Ukraine and its reasons}

The general positive characteristics of the institutional theory of accounting, in particular in the agricultural sector, include a wide range of research methods that are not only interdisciplinary in nature, but also include an organic approach, which is especially important for agriculture. At the same time, the application of the latter is rather complicated, because the features that are characteristic of the organic model, it is difficult to formalize and present in numerical terms. Therefore, there is a need to develop research in this area.

We can generally assert about the positive influence of the institutional theory on the organizational provisions of accounting in the agricultural sector, allow us to increase the accounting potential and look for new ways to solve problems that arise in modern conditions, because in fact the institutional approach focuses on the emergence of new economic phenomena. But it will be fair to admit that in fact, there is a focus directly on forecasting these phenomena, and the problem of their accounting display is solved only after they have appeared. That is, to a greater extent, one can be inclined to think that the scientific and cognitive function of accounting is developing, and not the prognostic one. But the real assessment of the process of institutionalization of accounting will be far from the truth, if the appropriate analysis is not carried out.

As a research method, we used a questionnaire survey (see Table 2) and, according to its results, it can be stated that, on the whole, the survey conducted showed that leading practicing specialists (as opposed to scientists), in essence, assign the value of symbolic, ordinary, semiotic values to institutions and practices, the consolidation and reproduction of which is carried out with the help of such social organizations as institutions (KARMAZINA; SHURBOVANA, 2006).

However, almost all respondents have information about accounting institutions consider the totality of formal and informal norms for the organization of accounting and the formation of accounting policies and execution mechanisms (POLENOVA, 2014), and institutional support (formal and informal institutions) affects the strengthening of the processes of diversification of accounting, which should focus on the creation of institutions. That is, the respondents know and critically assess the elements of institutional support for the development of accounting in Ukraine (see Figure 2) and critically assess its results for the agricultural sector). 
DOI: 10.14807/ijmp.v11i9.1440

In general, it should be noted that the systematic implementation of the institutional framework in accounting is largely determined not only by the level of readiness of a particular country in such innovations. A significant role in this context is played by such factors as the scope of such an accounting system (for example, industry, agriculture, etc.), the initial conditions for its implementation and the subjects of its initiation, the level of legal support, and so on.

A real objective assessment of the factors and reasons for the development of institutional foundations can be carried out by examining, in chronological order, the implementation of certain measures and making decisions in regulatory documents. This will make it possible not only to answer the question of whether the institutional framework for accounting is the result of an objective need for them, the result of pressure from the relevant institutions, but also to establish the type of their implementation and possible expected results. Having a certain empirical experience, for comparison, we implement this idea on the basis of agriculture (the importance of which was proved above).

The sources of the study are a strategy for improving accounting and measures implemented at the state level and implemented in accordance with it and other government decisions regarding the introduction of institutional frameworks for accounting in the agricultural sector of Ukraine. For clarity, we will group the obtained data in Table 4.

As can be seen from Table 4, in Ukraine, all measures for the implementation of the institutional framework for accounting in the agricultural sector, related to the need to comply with the approved regulatory documents.

Despite the fact that the overwhelming majority of senior executives in the agricultural sector and accounting specialists of large agricultural holdings are positive about the introduction of institutional frameworks in accounting, especially IFRS (as opposed to similar groups of workers of small and medium-sized enterprises), in Ukraine these principles, despite the assessment of the measures and normative acts, starting from 1996, is carried out using a coercive mechanism.

Professional accounting organizations are actually not very active in these processes, but they are involved in the development of draft regulatory documents, or their assessment. The main result of this pressure was the standardization of accounting (transition to national accounting standards based on the provisions of international standards). 
INDEPENDENT JOURNAL OF MANAGEMENT \& PRODUCTION (IJM\&P)

http://www.ijmp.jor.br

v. 11, n. 9, Special Edition (Baltic States), November 2020

ISSN: 2236-269X

DOI: 10.14807/ijmp.v11i9.1440

Table 4: Genesis of the implementation of the institutional framework for accounting in the agricultural sector of Ukraine

\begin{tabular}{|c|c|c|c|}
\hline Year & $\begin{array}{l}\text { Normative and legal } \\
\text { document, event, etc. }\end{array}$ & $\begin{array}{l}\text { The element of institutionalism that was } \\
\text { introduced }\end{array}$ & $\begin{array}{l}\text { Assessment of the } \\
\text { role of the } \\
\text { implemented } \\
\text { element by } \\
\text { practitioners } *\end{array}$ \\
\hline 1996 & $\begin{array}{c}\text { Law of Ukraine "On accounting } \\
\text { and financial reporting in Ukraine" } \\
\text { No. } 996\end{array}$ & Conceptual accounting framework & Overall positive \\
\hline 1998 & $\begin{array}{l}\text { Resolution of the Cabinet of } \\
\text { Ministers of Ukraine No. } 1706\end{array}$ & $\begin{array}{l}\text { Formation of P (S) BU and their harmonization } \\
\text { with IFRS. Development of professional and } \\
\text { educational institutions (formal institutions) }\end{array}$ & Overall positive \\
\hline 1999 & $\begin{array}{c}\text { Law of Ukraine "On accounting } \\
\text { and financial reporting in Ukraine" } \\
\text { P(S)A } 7 \text { "Fixed assets"; } 8 \\
\text { "Intangible assets"; } 9 \\
\text { "Inventories"; } 10 \text { "Accounts } \\
\text { Receivable"; } 16 \text { "Expenses", etc. }\end{array}$ & $\begin{array}{l}\text { Establishing principles and general accounting } \\
\text { principles. Regulation and organization of } \\
\text { accounting and financial reporting. } \\
\text { General approaches }\end{array}$ & Negative \\
\hline 2000 & $\begin{array}{l}\text { Tax Code of Ukraine (draft) } \\
\text { New Chart of accounts of } \\
\text { accounting }\end{array}$ & $\begin{array}{l}\text { Settlement of relations of taxation / in the field of } \\
\text { accounting, it is proposed to consider the } \\
\text { assessment of historical (actual) cost as a priority } \\
\text { Improving methodology }\end{array}$ & $\begin{array}{l}\text { Negative } \\
\text { Overall positive }\end{array}$ \\
\hline 2003 & $\begin{array}{l}\text { Methodological recommendations } \\
\text { for transforming the financial } \\
\text { statements of Ukrainian enterprises } \\
\text { into financial statements according } \\
\text { to IFRS No. } 112 \\
\end{array}$ & Harmonization, reporting mechanism & \\
\hline 2004 & First adoption of IFRS & - & Overall positive \\
\hline 2007 & $\begin{array}{l}\text { Strategy for applying IFRS } \\
\text { No. } 911\end{array}$ & $\begin{array}{c}\text { Streamlining and improving the IFRS } \\
\text { implementation process. } \\
\text { Implementation of international and European } \\
\text { approaches. } \\
\text { Development of professional and educational } \\
\text { institutions (formal institutions) }\end{array}$ & Overall positive \\
\hline 2009 & $\begin{array}{l}\text { The Concept for the development } \\
\text { of Accounting in the Agricultural } \\
\text { sector of the Ukrainian economy, } \\
\text { approved by the Board of the } \\
\text { Ministry of Agrarian Policy of } \\
\text { Ukraine dated 03.02.2009, Protocol } \\
\text { № } 1 \text { Minutes No. } 1\end{array}$ & $\begin{array}{l}\text { Establishment of general principles for the } \\
\text { development, functioning and improvement of } \\
\text { the accounting and reporting system in the } \\
\text { agricultural sector of the Ukrainian economy } \\
\text { (identification of management bodies in the field } \\
\text { of accounting for the agro-industrial complex, } \\
\text { professional public associations, development } \\
\text { and improvement of P(S)A and other regulatory } \\
\text { legal acts on accounting; formation of conditions } \\
\text { development of the profession of an accountant, } \\
\text { etc. }\end{array}$ & positive \\
\hline 2010 & Tax Code of Ukraine & $\begin{array}{l}\text { Establishment of approaches to taxation / in the } \\
\text { field of accounting, the problem of composition } \\
\text { of expenses (including Transactional) was solved }\end{array}$ & Overall positive \\
\hline 2012 & $\begin{array}{l}\text { Order of the Cabinet of Ministers } \\
\text { of Ukraine No. 157-r }\end{array}$ & $\begin{array}{l}\text { Development of conditions for the } \\
\text { implementation of IFRS }\end{array}$ & Overall positive \\
\hline 2017 & $\begin{array}{c}\text { Law of Ukraine "On Amendments } \\
\text { to the Law of Ukraine" On } \\
\text { Accounting and Financial } \\
\text { Reporting in Ukraine " } \\
\end{array}$ & $\begin{array}{l}\text { Bringing accounting in Ukraine to the standards } \\
\text { of the European Union }\end{array}$ & positive \\
\hline 2018 & $\begin{array}{l}\text { Methodological recommendations } \\
\text { for drawing up a management } \\
\text { report No. } 982\end{array}$ & $\begin{array}{l}\text { Harmonization of reporting, development of } \\
\text { management reporting }\end{array}$ & positive \\
\hline
\end{tabular}

Source: Generated and summarized based on the results of a survey of 105 respondents. The result was shown if $75 \%$ of the respondents gave the same assessment 
DOI: 10.14807/ijmp.v11i9.1440

The study of the reasons for the approval of most of the normative legal documents is associated with European integration. In particular, the requirement for the transition of Ukrainian accounting to IFRS is spelled out in the Association Agreement with the EU (ASSOCIATION AGREEMENT BETWEEN UKRAINE, ON THE ONE HAND, AND THE EUROPEAN UNION, THE EUROPEAN ATOMIC ENERGY COMMUNITY AND THEIR MEMBER STATES, ON THE OTHER HAND: JOINT DECLARATION, 2014).

However, despite this, the management of agricultural enterprises of various levels, especially the top ones (heads of agricultural holdings and their marketing departments, financial directors, chief accountants and economists) believe that the institutionalization of accounting, especially in terms of standardization and application of IFRS and the development of professional organizations and educational institutional component - the objective need of modern agricultural holdings.

To substantiate our conclusions, we present some more statistical data. Figure 4 illustrates the dynamics of agricultural production in Ukraine.

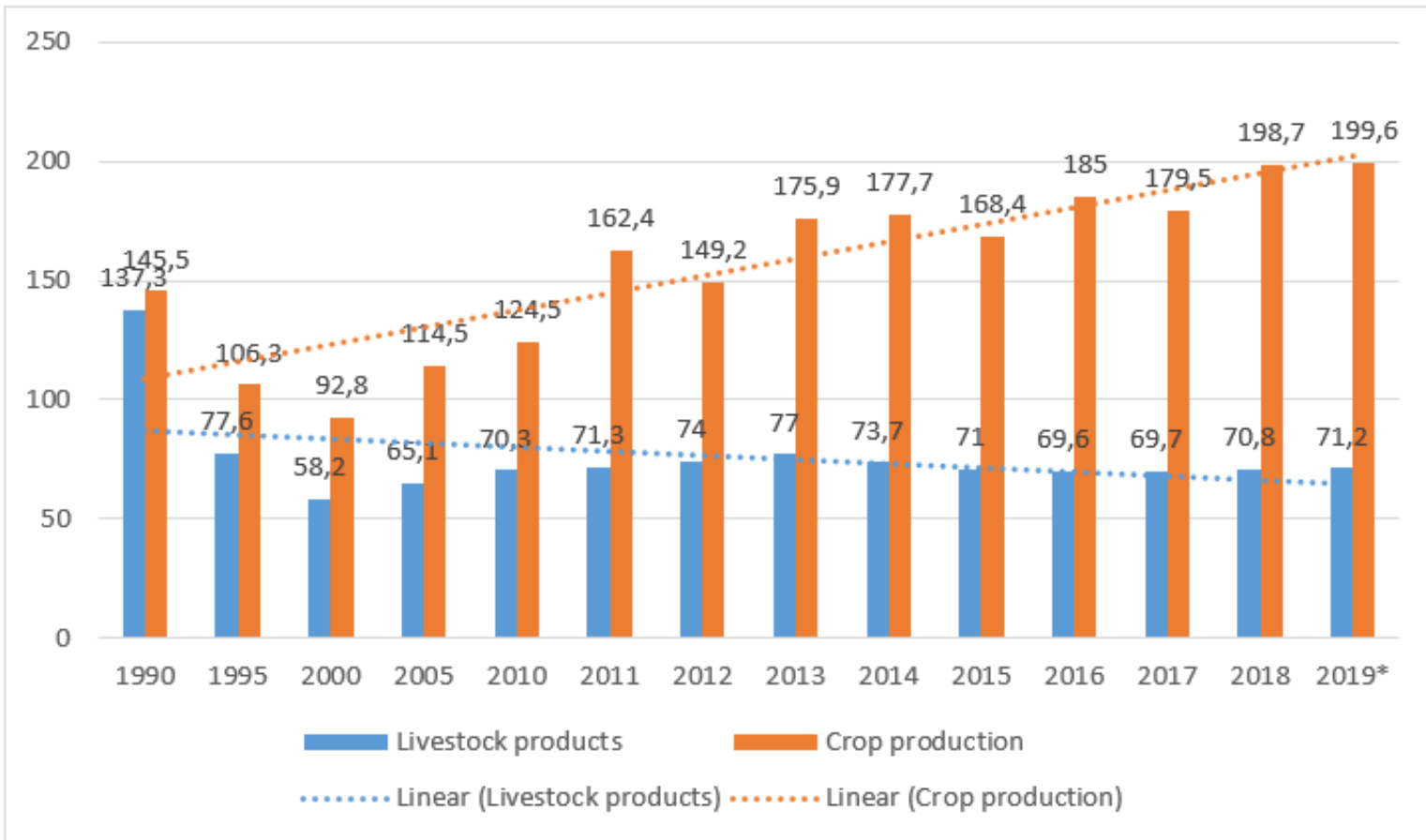

Figure 4: Dynamics of agricultural production in Ukraine for 1990-2019, bln. UAH. Notes: by 2019 - unofficial data; sources of chart construction (AGRICULTURE OF UKRAINE: STATISTICAL YEARBOOK, 2018; DUGIENKO; LEVA, 2018)

The figure shows the dynamic growth of agricultural production, in particular crop production. This is precisely what the data in Table 5 indicate.

Accordingly, the agricultural sector needs to expand markets, and therefore agricultural enterprises, especially Agro Holdings, are interested in developing international cooperation 
DOI: 10.14807/ijmp.v11i9.1440

on these issues. In turn, such cooperation is more actively developed in the presence of a transparent and understandable for all accounting system. The latter meets this criterion subject to the development of institutional frameworks, including those related to the application of IFRS.

Table 5: Indices of the physical volume of agricultural products sold by Ukrainian enterprises $(1997-2019) *$ (in\% to the previous year)

\begin{tabular}{|c|c|c|c|}
\hline \multirow{2}{*}{ Year } & Agricultural products - total & \multicolumn{2}{|c|}{ Including } \\
\cline { 3 - 4 } & & Crop production & Livestock products \\
\hline 1997 & 111,0 & 143,5 & 78,2 \\
\hline 1998 & 83,1 & 79,0 & 91,5 \\
\hline 1999 & 92,9 & 91,9 & 94,3 \\
\hline 2000 & 95,4 & 97,0 & 93,0 \\
\hline 2001 & 111,8 & 124,3 & 87,6 \\
\hline 2002 & 109,9 & 108,6 & 112,5 \\
\hline 2003 & 84,7 & 74,3 & 104,4 \\
\hline 2004 & 124,7 & 141,6 & 96,7 \\
\hline 2005 & 110,3 & 112,4 & 106,8 \\
\hline 2006 & 111,4 & 109,4 & 114,1 \\
\hline 2007 & 96,0 & 86,3 & 111,8 \\
\hline 2008 & 126,8 & 140,9 & 103,6 \\
\hline 2009 & 120,0 & 128,4 & 108,3 \\
\hline 2010 & 95,8 & 90,1 & 107,8 \\
\hline 2011 & 112,0 & 114,5 & 106,9 \\
\hline 2012 & 117,5 & 122,9 & 105,3 \\
\hline 2013 & 110,6 & 111,4 & 108,6 \\
\hline 2014 & 107,7 & 108,7 & 105,3 \\
\hline 2015 & 106,9 & 111,1 & 95,4 \\
\hline 2016 & 87,9 & 83,4 & 105,1 \\
\hline 2017 & 107,5 & 108,3 & 103,1 \\
\hline 2018 & 105,7 & 107,2 & 98,8 \\
\hline 2019 & 114,1 & 116,9 & 101,2 \\
\hline
\end{tabular}

Note: * - for 2014-2019 the data are given without taking into account the temporarily occupied territory of the Autonomous Republic of Crimea, Sevastopol and parts of the temporarily occupied territories in Donetsk and

In fact, this is why the results of the survey show the interest of respondents from large agricultural enterprises in the process of implementing IFRS. It follows that the development of the institutional framework of accounting for agriculture is an objective necessity. An additional result of the survey is the respondents' recommendations regarding the requirements for specialists. They concluded that the need for development and professional development of education. In particular, the collected recommendations of respondents on the educational institutional component indicate that in modern conditions the management of large Agro Holdings needs specialists with knowledge of IFRS and foreign languages (mainly English), as well as skills of economic analysis. 
DOI: 10.14807/ijmp.v11i9.1440

\subsection{Institutionalization of accounting in the public sector}

A somewhat different situation is observed in such a significant industry for the state as the public (public sector).

The results of a questionnaire survey of management workers at various levels of the public sector (see Table 3) show the opposite result than that obtained from the institutionalization of accounting in the agricultural sector of Ukraine.

The results of the questionnaire survey indicate that the respondents - the main managers and government officials consider the development of the institutional foundations of accounting in the public sector associated with the need to harmonize Ukrainian legislation with the requirements of international legislation, the need to regulate at the legislative level the issue of the method of reflecting in accounting all transactions that are carried out entities financed from the budget, as well as the lack of the ability to compare data on the financial condition of the state with similar reporting data from other countries.

Another conclusion follows from a survey of respondents of public (state) sector entities that belong to the group of lower-level budget funds managers. Almost all respondents (with the exception of senior management, namely the main administrators of budgetary funds) consider the institutionalization of accounting in the public (public sector) inappropriate and imposed by its highest authorities and administration.

In particular, we are talking about the employees of the leading links of budgetary institutions and specialists in the field of accounting with over 25 years of experience. They believe that the reform of accounting in the public sector of Ukraine is not giving the desired positive results.

Moreover, accountants of the older generation express the opinion that the accounting system, which was carried out before the start of its reform in the public sector, namely in compliance with Instruction No. 61 (STATE TREASURY UKRAINE, 2000) was simpler, more understandable and provided a better information base for the management of budgetary funds than that which is now conducted using national regulations (standards) of public sector accounting and the new Plan introduced in January 2017 accounting accounts. In addition, given that the public (public) sector is largely financed from budget funds, the accounting that was led to the reform provided more transparent information to control their spending.

As an argument in favour of this statement, we will give an example of the dynamics of the volume of funds in the Treasury accounts as of January 1 through 2013-2020 (Figure 5). 
DOI: 10.14807/ijmp.v11i9.1440



Figure 5: Dynamics of funds in the accounts of the Treasury of Ukraine as of 01.01, bln. $\mathrm{UAH}$ Source: STATE TREASURY SERVICE OF UKRAINE, 2020

Despite the fact that this indicator has some subjective character, it illustrates some tendencies. In particular, we see a significant growth of the currency in the treasury account. But, starting in 2017, when the measures to modernize the accounting system in the public sector were fully implemented, including the introduction of national accounting standards based on the provisions of international ones, as well as the new Chart of Accounts, the growth in the volume of funds was only in 2018.

In subsequent years, a dynamic decrease can be traced. Therefore, there is no reason to believe that there have been significant positive shifts in order to substantiate the objectivity of the introduction of institutional frameworks into accounting in the public sector. It follows from this that institutional changes in the accounting system of this sector are probably the result of public pressure.

\section{CONCLUSIONS AND RECOMMENDATIONS}

Thus, the application of the institutional approach and the development of the institutional framework in accounting will allow it to modernize and expand the traditional ways of perception, focusing on the modern requirements of society. An important aspect is the introduction of global trends in the development of the accounting system in Ukraine, especially IFRS. The introduction of the norms of international financial reporting standards will help the state to enter the communities of countries that have a significant impact on the development of the accounting system, would allow taking into account the national interests of the Ukrainian economy. 


\section{REFERENCES}

AGRICULTURE OF UKRAINE: STATISTICAL YEARBOOK (2018) Accountable for issue O.M. Prokopenko. Kyiv.

CABINET OF MINISTERS OF UKRAINE (1998) The program of reforming the accounting system using international accounting standards: Resolution of the Cabinet of Ministers of Ukraine, dated October 29, n. 1706.

CABINET OF MINISTERS OF UKRAINE (2007) Strategy for applying IFRS: Order of the Cabinet of Ministers of Ukraine. Kyiv, n. 911-r dated 24.10.2007

CABINET OF MINISTERS OF UKRAINE (2012) On creating conditions for the implementation of international financial reporting standards: Resolution of the Cabinet of Ministers of Ukraine n. 157-r dated February 22, 2012.

CARPENTERA, V. L.; FEROZ, E. H. (2001) Institutional theory and accounting rule choice: An analysis of four US state governments' decisions to adopt generally accepted accounting principles. Accounting Organizations and Society, v. 26, n. 7-8, p. 565-596. DOI: 10.1016/S0361-3682(00)00038-6

CONCLUSION ON THE DRAFT TAX CODE OF UKRAINE (2010) n. 16 / 3-788 / 7101-1 / Available: https://ips.ligazakon.net/document/NT0061

DUGIENKO, N. O.; LEVA, V. E. (2018) Modern Trends in the development of Agricultural Sector of Ukraine. Infrastruktura rynku, v. 25, p. 99-107. Available: http://www.marketinfr.od.ua/journals/2018/25_2018_ukr/19.pdf

GONCHARENKO, I. M. (2013) The effect of institutional environment of accounting. Bulletin of the Chernihiv State Technological University, v. 3, n. 68, p. 52-60.

GUERREIRO, M. S.; RODRIGUES, L. L.; CRAIG, R. (2020) Institutional Theory and IFRS: An agenda for future research. Revista Espanola de Financiacion y Contabilidad. DOI: $10.1080 / 02102412.2020 .1712877$

GUERREIRO, M. S.; RODRIGUES, L. L.; CRAIG, R. (2020b). Understanding the Process of Convergence with IFRS Using Institutional Theory. Conference Paper. XIX Conferência e Doctoral Colloquium, IPCA, Barcelos, Portugal.

HAMILTON, W. H. (1919) The Institutional Approach to Economic Theory. American Economic Review, n. 9, p. 309-318.

KARMAZIN, M.; SHURBOVANA, A. (2006) "Institute" and "Organization": the problem of distinguishing between concepts. Political management, n. 4, p. 10-19.

KHADAROO, I. (2005) An institutional theory perspective on the UK's Private Finance Initiative (PFI) accounting standard setting process. Public Management Review, v. 7, n. 1, p. 69-94 - March 2005 with 191 Reads. DOI: 10.1080/1471903042000339428. Available: https://www.researchgate.net/publication/338833329_Understanding_the_Process_of_Conve rgence_with_IFRS_Using_Institutional_Theory

KHORUNZHAK, N.; SEMENYSHENA, N.; ADAMYK, O.; SADOVSKA, I.; NAHIRSKA, K.; ZHUK, V. (2019) The methodology for calculating baseline indicators for budgeting expenditures of budgetary institutions: the case of Ukraine. Intellectual Economics. 2019. v. 13, n. 1. p. 40-45. DOI (PDF): https://doi.org/10.13165/IE-19-13-1-04 
INDEPENDENT JOURNAL OF MANAGEMENT \& PRODUCTION (IJM\&P)

http://www.ijmp.jor.br

v. 11, n. 9, Special Edition (Baltic States), November 2020

ISSN: 2236-269X

DOI: 10.14807/ijmp.v11i9.1440

KOLESNIKOVA, A. N. (2013) Development of accounting in the context of institutional change. Scientific Bulletin of the National University of Bioresources and Nature

Management of Ukraine. Ser.: Economics, agricultural management, business, v. 181, n. 3, p. 111-115. Available: http://www.irbis-nbuv.gov.ua/cgi-

bin/irbis_nbuv/cgiirbis_64.exe?I21DBN=LINK\&P21DBN=UJRN\&Z21ID=\&S21REF=10\& S21CNR=20\&S21STN=1\&S21FMT=ASP_meta\&C21COM=S\&2_S21P03=FILA=\&2_S21 STR=nvnau_econ_2013_181\%283\%29_22. Acess: 17 June 2020

KUZMINOV, I.; RADAEV, V.; YAKOVLEV, A.; YASIN, E. (2005) Institutions: from borrowing to cultivation. Questions of economy, n. 5, p. 5-27. Available :

https://iro.hse.ru/data/584/071/1228/voprosyec5-05.pdf. Acess: 12 June 2020

MELNICHUK, B.V. (2011) Problems of IFRS implementation in Ukraine: an institutional approach. Accounting and Finance, v. 3, p. 23-27. Available:

http://magazine.faaf.org.ua/problemi-zaprovadzhennya-msfz-v-ukraini-institucionalniypidhid.html. Acess:

MINISTRY OF DEVELOPMENT OF COMMUNITIES AND TERRITORIES OF UKRAINE (2020) Analysis of socio-economic development of regions for January September 2019. Kyiv. Available: https://www.minregion.gov.ua/wpcontent/uploads/2019/12/Analiz-sotsialno-ekonomichnogo-rozvitku-regioniv-za-sichenveresen-2019-roku.pdf. Acess: 26 June 2020.

MINISTRY OF FINANCE OF UKRAINE (1999) Chart of accounts for accounting of assets, capital, liabilities and business operations of enterprises and organizations and Instructions for its use: order of the Ministry of Finance of Ukraine, n. 291 (taking into account changes and additions, the last of which were introduced by order of the Ministry of Finance of Ukraine No. 48 dated 02/08/2014).

MINISTRY OF FINANCE OF UKRAINE (2010) Tax Code of Ukraine: Law of Ukraine dated 02.12.2010 No. 2755-VI. Available: http: // zakon.rada.gov.ua

MINISTRY OF FINANCE OF UKRAINE (2017) Law of Ukraine "On Accounting and Financial Reporting in Ukraine" (2017) No. 2164-VIII. Available:

https://zakon.rada.gov.ua/laws/show/2164-19\#Text

MINISTRY OF FINANCE OF UKRAINE (2018) Methodological recommendations for drawing up a management report: Order of the Ministry of Finance of Ukraine dated 07.12.2018, n. 982.

MINISTRY OF REGIONAL DEVELOPMENT, CONSTRUCTION AND HOUSING OF UKRAINE (2016) Monitoring of socio-economic development of the regions for January-December 2015. Presentation. Department of Regional Development. Kyiv. Available: https://www.minregion.gov.ua/wp-content/uploads/2016/05/Otsinka-sotsialnoekonomichnogo-rozvitku-regioniv-za-2015-r.-prezentatsiyni-materiali2.pdf. Acess: 26 June 2020.

MINISTRY OF REGIONAL DEVELOPMENT, CONSTRUCTION AND HOUSING OF UKRAINE (2017) Monitoring of socio-economic development of the regions for January-December 2016. Presentation. Department of Regional Development. Kyiv. Available: https://www.minregion.gov.ua/wp-content/uploads/2017/05/Reytingova-otsinkaza-2016-rik-prezentatsiyni-materiali.pdf. Acess: 26 June 2020.

MINISTRY OF REGIONAL DEVELOPMENT, CONSTRUCTION AND HOUSING OF UKRAINE (2018) Monitoring of socio-economic development of the regions for January-December 2017. Presentation. Kyiv: Department of Regional Development.. 
INDEPENDENT JOURNAL OF MANAGEMENT \& PRODUCTION (IJM\&P)

http://www.ijmp.jor.br

v. 11, n. 9, Special Edition (Baltic States), November 2020

ISSN: 2236-269X

DOI: 10.14807/ijmp.v11i9.1440

Available: https://www.minregion.gov.ua/wp-content/uploads/2018/05/Reytingova-otsinkaza-2017-rik-prezentatsiyni-materiali.pdf. Acess: 26 June 2020.

MINISTRY OF REGIONAL DEVELOPMENT, CONSTRUCTION AND HOUSING OF UKRAINE (2019) Monitoring of socio-economic development of the regions for January-December 2018. Presentation. Kyiv: Department of Regional Development. Available: https://www.minregion.gov.ua/wp-content/uploads/2019/05/Reytingova-otsinkaza-2018-rik-prezentatsiyni-materiali.pdf. Acess: 26 June 2020.

NAGENDRAKUMAR, N. (2019) Revisiting Institutional Theory: Accrual Accounting Reform in Public Sector, Sri Lanka. Annual Conference-Association of Public Finance Accountants of Sri Lanka (public sector wing of Institute of Chartered Accountants of Sri Lanka), Colombo, p. 61-69. Available:

https://www.researchgate.net/publication/331298813. Acess: 20 June 2020.

NORTH, D. (1990) Institutions, institutional change and economic performance. New York : Cambridge University Press.

ON ACCOUNTING AND FINANCIAL REPORTING IN UKRAINE: LAW OF UKRAINE (1996) n. 996.

PANKOV, V. V. (2011) Institutional Theory of Accounting and Auditing. Moskow: Inform-Biuro.

POLENOVA, S. N. (2014) Categories of Institutional Theory in the development of Accounting. Audit and financial analysis, n. 1, p. 57-62.

RADCHENKO, O.; SEMENYSHENA, N.; SADOVSKA, I.; NAHIRSKA, K.; POKOTYLSKA, N. (2020c) Foresight Development Strategy of the Financial Capacity: Comparative Study of the Ukrainian Agricultural Sector. Engineering Economics, v. 31, n. 2, p. 178-187. DOI: https://doi.org/10.5755/j01.ee.31.2.24340.

RIBEIRO, J. A.; SCAPENS, R. W. (2006) Institutional theories in management accounting change: Contributions, issues and paths for development. Qualitative Research in Accounting \& Management, v. 3, n. 2, p. 94-111. DOI: 10.1108/11766090610670640

SEMANYUK, V. (2012) Accounting theory: an institutional approach. Economic analysis, v. 11, n. 4, p. 281-284. Available: http://www.irbis-nbuv.gov.ua/cgi-

bin/irbis_nbuv/cgiirbis_64.exe?I21DBN=LINK\&P21DBN=UJRN\&Z21ID=\&S21REF=10\& $\mathrm{S} 21 \mathrm{CNR}=20 \& \mathrm{~S} 21 \mathrm{STN}=1 \& \mathrm{~S} 21 \mathrm{FMT}=\mathrm{ASP} \_$meta\&C21COM=S\&2_S21P03=FILA=\&2_S21 STR=ecan_2012_11\%284\%29_60. Acess: 18 June 2020.

SEMENYSHENA, N. (2016) Traditional and new institutional aspects in accounting theory. The strategy for the balanced use of the economic, technological and resource potential of the country: Collection of scientific papers of the II International Scientific and Practical Conference (June 1, 2016, Kamianets-Podilskyi, p. 209-211). Ternopil: Krok.

SEMENYSHENA, N.; KHORUNZHAK, N.; SADOVSKA, I. (2020) Evaluation of the adaptability of scientific theories for the development of Accounting Institute. Intellectual Economics, v. 14, n. 1. p. 113-129. DOI: https://doi.org/10.13165/IE-20-14-1-07.

SEMENYSHENA, N.; KHORUNZHAK, N.; ZADOROZHNYI, Z.-M. (2020) The institutionalization of Accounting: the impact of National standards on the development of economies. Independent Journal of Management \& Production, v. 11, n. 8, p. 695-711. DOI: dx.doi.org/10.14807/ijmp.v11i8.1228. 
INDEPENDENT JOURNAL OF MANAGEMENT \& PRODUCTION (IJM\&P)

http://www.ijmp.jor.br

v. 11, n. 9, Special Edition (Baltic States), November 2020

ISSN: 2236-269X

DOI: 10.14807/ijmp.v11i9.1440

SLYUZ, T. (2018) Public report of the head of the treasury on the results of the activities of the State Treasury Service of Ukraine in 2018. Available:

<https://www.treasury.gov.ua/storage/app/sites/1/\%20\%D0\%97\%D0\%92\%D0\%86\%D0\%A2 \%20\%D0\%93\%D0\%9E \% D0\% 9B\% D0\% 9E\% D0\% 92\% D0\% 98\% 20\% D0\% 94\% D0\% 9A\% D0\% A1\% D0\% A3\% 202018.pdf>. Acess: 27 June 2020.

STATE COMMISSION ON SECURITIES AND STOCK MARKET (2003) Methodological recommendations for transforming the financial statements of Ukrainian enterprises into financial statements according to IFRS: Decision of the State Commission on Securities and Stock Market No. 112 dated 01.04.2003.

STATE STATISTICS SERVICE OF UKRAINE (2019) Volume indices of agricultural products sold by enterprises. Economic statistics. Agriculture, forestry and fisheries section. Available:

<http://www.ukrstat.gov.ua/operativ/operativ2019/sg/ifosg_reagn/ifosg_reagn_97_18u.htm>. Acess: 28 June 2020.

STATE TREASURY OF UKRAINE (2000) On approval of the instruction on the correspondence of accounting subaccounts to reflect the main business operations of budgetary institutions: Order of the dated July 10, 2000, n. 61.

STATE TREASURY SERVICE OF UKRAINE (2020) The main numbers. Available: <https://www.treasury.gov.ua/ua/main-figures>. Acess: 29 June 2020.

SYSOEV, A. V. (2014) The concept of "institution" and "organization": the economic context. Bulletin of Zaporizhzhya National University, v. 3, n. 23, p. 140-149. Available: $<$ http://irbis-nbuv.gov.ua/cgi-

bin/irbis_nbuv/cgiirbis_64.exe?C21COM=2\&I21DBN=UJRN\&P21DBN=UJRN\&IMAGE_F ILE_DOWNLOAD=1\&Image_file_name=PDF/Vznu_eco_2014>. Access: 02 July 2020

THE ASSOCIATION AGREEMENT BETWEEN UKRAINE, ON THE ONE HAND, AND THE EUROPEAN UNION, THE EUROPEAN ATOMIC ENERGY COMMUNITY AND THEIR MEMBER STATES, ON THE OTHER HAND: JOINT DECLARATION (2014) No. 984_011 of 21.03. 2014 Available: https://www.kmu.gov.ua/diyalnist/yevropejskaintegraciya/ugoda-pro-asociacyu. Acess: 29 June 2020.

THE CONCEPT OF DEVELOPMENT OF ACCOUNTING IN THE AGRICULTURAL SECTOR OF THE ECONOMY. Available: <http://magazine.faaf.org.ua/koncepciyarozvitku-buhgalterskogo-obliku-v-agrarnomu-sektori-ekonomiki-ukraini-1287.html>. Access: 16 June 2020.

VOSKRESENSKAYA, N. V.; LVOVA, M. V. (2011) An institutional approach to accounting. Bulletin of the Chuvash University. Economy, n. 4, p. 359-362. Available: $<$ https://cyberleninka.ru/article/n/institutsionalnyy-podhod-v-buhgalterskom-uchete/viewer> Access: 11 June 2020.

VYSOCHAN, A. S.; YAKHVAK, D. M. (2017) Institutionalism in modern national accounting theory: historical origins and genesis. Prychornomorski Ekonomichni Studii, n. 16, p. 155-162. Available: <http://bses.in.ua/journals/2017/16_2017/34.pdf>. Access: 10 June 2020.

WATTS, R. L.; ZIMMERMAN, J. L. (1990) Positive Accounting Theory: A Ten Year Perspective. The Accounting Review, v. 65, n. 1, p. 131-156.

ZHUK, V. M.; BEZDUSHNA, YU.; TYVONCHUK, S. (2019) Improvement of IFRS application policy in relation to land assets of agricultural enterprises. Independent Journal 
ISSN: 2236-269X

DOI: 10.14807/ijmp.v11i9.1440

of Management \& Production, v. 10, n. 7, p. 702-724. DOI: 10.14807/ijmp.v10i7.889.

URL: http://www.ijmp.jor.br/ index.php/ijmp/article /view/889

ZHUK, V. M. (2010) Institutional support for the development of accounting in Ukraine. Finance of Ukraine, v. 11, p. 101-110.

ZHUK, V. M. (2012) Deepening the essence of the subject of accounting. Accounting and Finance of the Agro-Industrial Complex, n. 1, p. 16-23. 